\title{
HUBUNGAN PAPARAN DEBU DENGAN KAPASITAS FUNGSI PARU PERAJIN BATU PARAS DI DESA KETEWEL, SUKAWATI, GIANYAR
}

\author{
Putu Wulan Putri Amerta*, I Made Ady Wirawan \\ Program Studi Sarjana Kesehatan Masyarakat Fakultas Kedokteran Universitas Udayana \\ *email : wulanputrri@gmail.com
}

\begin{abstract}
ABSTRAK
Kapasitas fungsi paru merupakan kesanggupan paru-paru dalam menampung udara didalamnya. Perajin batu paras yang bekerja di lingkungan yang terpapar debu dalam jangka panjangnya akan menimbulkan penyakit akibat kerja salah satunya berupa gangguan kapasitas fungsi paru. Tujuan penelitian ini untuk menganalisis hubungan antara faktor individu dan konsentrasi paparan debu dengan kapasitas fungsi paru pada perajin batu paras di Desa Ketewel, Sukawati, Gianyar. Penelitian ini merupakan penelitian cross-sectional analitik. Responden penelitian ini adalah seluruh perajin batu paras yang ada di Desa Ketewel yang berjumlah 60 orang. Data dianalisis secara univariat, bivaraiat dengan uji Chi-square, dan multivariate dengan multiple logistic regression. Hasil penelitian menunjukkan sebanyak $56,67 \%$ perajin batu paras mengalami gangguan kapasitas fungsi paru. Faktor yang berhubungan secara signifikan dengan kapasitas fungsi paru adalah paparan debu $(\mathrm{p}=0,04 ; \mathrm{OR}=4,70$; 95\% CI 1,09-20,24). Disimpulkan bahwa paparan debu berhubungan signifikan dengan kapasitas fungsi paru perajin batu paras di Desa Ketewel. Disarankan kepada pemilik usaha batu paras bekerjasama dengan pihak kesehatan keselamatan kerja setempat dalam hal sosialisasi bahaya penyakit akibat kerja khususnya bahaya paparan debu.
\end{abstract}

Kata Kunci: Paparan Debu, Perajin Batu Paras, Faktor Individu, Kapasitas Fungsi Paru

\begin{abstract}
The pulmonary function capacity is the ability of the lungs to hold air in it. Paras stone Artisan who work in the environment which exposed to dust in the long run will cause work-related diseases, one of them is a disruption of lung function capacity. The purpose of this study is to analyze the relationship between individual factors and the concentration of dust exposure with lung function capacity in sandstone artisans in Ketewel Village. This study is an analytical cross-sectional study. The respondents of this study were all paras stone artisans in Ketewel Village, which numbered 60 people. Data were analyzed by univariate, bivariate with Chi-square test, and multivariate with multiple logistic regression. The results showed that $56.67 \%$ of paras stone artisans had pulmonary function capacity. Factors significantly associated with pulmonary function capacity were exposure to dust ( $\mathrm{p}=0,04 ; \mathrm{OR}=4.70 ; 95 \%$ CI 1.09-20.24). It was concluded that dust exposure was significantly associated with pulmonary function capacity of paras stone artisans in Ketewel Village. It is recommended to the business owner of the sandstone to work with the local occupational health authorities in terms of socializing the dangers of occupational diseases, especially the danger of dust exposure.
\end{abstract}

Key words: Paras Stone Artisan, Dust Exposure, Individual Factor, Pulmonary Function Capacity

\section{PENDAHULUAN}

Menurut International Labor

Organization (ILO) setiap tahun terjadi 1,1

juta kematian yang disebabkan oleh

penyakit atau yang disebabkan oleh pekerjaan. Sekitar 300.000 kematian terjadi dari 250 juta kecelakaan dan sisanya adalah kematian karena penyakit akibat kerja dimana diperkirakan terjadi 160 juta penyakit akibat hubungan pekerjaan baru setiap tahunnya dan juga data yang dilaporkan oleh ILO meneyatakan bahwa penyebab kematian yang berhubungan dengan pekerjaan yang disebabkan oleh gangguan pernapasan yaitu sebesar $21 \%$ (ILO, 2002).

Penyakit saluran pernapasan akibat kerja, sesuai dengan hasil riset The Surveillance of Work Related and Occupational Respiratory Disease (SWORD) 
yang dilakukan di Inggris, ditemukan 3300 kasus baru penyakit paru yang berhubungan dengan pekerjaan. Tidak hanya industri-industri besar, industri kecil seperti industri rumahan pun tenaga kerjanya dapat terancam penyakit akibat kerja apabila tidak memperhatikan proses kerja dengan baik, salah satunya seperti industri rumahan kerajinan batu paras. Terlebih lagi industri rumahan pastinya kurang memperhatikan keselamatan dan kesehatan pekerja saat proses produksi berlangsung.

Pulau Bali merupakan salah satu daerah pariwisata yang terkenal akan adat istiadat dan budayanya yang unik, dimana hal tersebut menjadi daya tarik pariwisata. Selain itu, salah satu daya tarik wisata di Bali adalah bentuk arsitektur dan aksesoris bangunannya. Bangunanbangunan di Bali seperti candi bentar, relief-relief tembok, patung-patung dan sebagainya sebagian besar menggunakan batu paras sebagai bahan dasar. Seiring dengan perkembangan jaman dan tumbuhnya arsitektur modern, ternyata penggunaan batu paras masih terus berkembang hingga saat ini sehingga perajin batu paras di Bali dapat dikatakan sangat mendukung sektor pariwisata.

Batu paras merupakan salah satu batu alam yang diketahui mengandung debu yang dapat menyebabkan gangguan pernapasan apabila terpapar secara terus menerus dalam kurun waktu yang lama, dimana debu ini muncul karena terjadinya proses pemotongan, pengeboran, peledakan atau proses lainnya yang menghasilkan partikel berukuran kecil. Apabila perajin batu paras terus terpapar debu maka dampaknya bagi kesehatan dapat menyebabkan gangguan fungsi paru pekerja itu sendiri dan jangka panjangnya dapat menimbulkan penyakit pneumokoniosis. Berdasarkan surat edaran Menteri Tenaga Kerja No. SE 01/MEN/1997 tentang Nilai Ambang Batas Faktor Kimia di Udara sebesar $3 \mathrm{mg} / \mathrm{m}^{3}$.

Data penelitian tentang paparan debu yang dihadapi oleh perajin batu paras di Bali belum cukup banyak ditemukan, oleh karena itu penulis ingin melakukan penelitian tentang hubungan paparan debu dengan kapasitas fungsi paru perajin batu paras di Desa Ketewel, Kecamatan Sukawati, Gianyar.

\section{METODE}

Desain penelitian ini merupakan penelitian analitik dengan pendekatan cross sectional. Sampel dalam penelitian ini adalah 60 perajin batu paras yang ada di Desa Ketewel, Sukawati, Gianyar. Sampel dipilih menggunakan teknik total sampling, yaitu semua perajin batu paras di Desa Ketewel diambil untuk dijadikan sampel. Data primer dikumpulkan kuantitatif menggunakan kuesioner dengan metode wawancara dan juga pengukuran paparan debu menggunakan alat Personal Dust Sampler (PDS), indeks massa tubuh (IMT) menggunakan microtoise dan timbangan pegas, dan juga dilakukan pengukuran kapasitas fungsi paru menggunakan alat spirometer. Variabel pada penelitian ini adalah paparan debu batu paras, umur, jenis kelamin, masa kerja, status gizi (IMT), penggunaan alat pelindung diri (APD), durasi kerja, kebiasaan merokok, dan kapasitas fungsi paru. Data yang diperoleh kemudian akan dikumpulkan dan selanjutnya dianalisis secara statistik untuk mengetahui hubungan variabel 
bebas dengan variabel tergantung menggunakan aplikasi pengolah data. Teknik dan instrumen pengumpulan data yang digunakan adalah kuesioner, penilaian status gizi, dan juga pengukuran untuk mengetahui hubungan paparan debu dengan kapasitas fungsi paru pada perajin batu paras. Penelitian ini telah diperiksa sesuai ethical clearance dari Komisi Etik Penelitian Litbang FK Unud/RSUP Sanglah dengan nomor 1631/UN14.2.2.VII.14/LP/2019 tertanggal 27 Mei 2019.

\section{HASIL}

Tabel 1. Distribusi Frekuensi Berdasarkan Karakteristik Perajin Batu Paras

\begin{tabular}{lcc}
\hline \multicolumn{1}{c}{ Karakteristik Responden } & Frekuensi (f) & Proporsi (\%) \\
\hline Umur & 15 & 25 \\
20-29 Tahun & 32 & 53,3 \\
30-39 Tahun & 13 & 21,7 \\
40-49 Tahun & & \\
\hline Jenis Kelamin & 60 & 100 \\
Laki-laki & 0 & 0 \\
Perempuan & & \\
\hline Status Gizi & 32 & 0 \\
Normal & 0 & 46,7 \\
Kurang & 28 & 30 \\
Lebih & & 70 \\
\hline Masa Kerja & 18 & \\
$<8$ tahun & 42 & 3,3 \\
$\geq 8$ tahun & & 96,7 \\
\hline Kebiasaan Merokok & 2 & 8,3 \\
Tidak merokok & 58 & 91,7 \\
Merokok & & 68,3 \\
\hline Penggunaan APD & 5 & 31,7 \\
Baik & 55 & \\
Tidak baik & & \\
\hline Durasi Kerja & 41 & \\
$\leq 8$ jam & 19 & \\
$>8$ jam & & \\
\hline
\end{tabular}

Tabel 2. Paparan Debu pada Perajin Batu Paras

\begin{tabular}{|c|c|c|}
\hline Kategori & Frekuensi (n) & Proporsi (\%) \\
\hline$\leq \mathrm{NAB}^{*}$ & 45 & 75 \\
\hline$>$ NAB & 15 & 25 \\
\hline
\end{tabular}

* Menurut Peraturan Kemenakertrans RI No.13 Tahun 2011 Nilai Ambang Batas (NAB)

Debu tidak melebihi 3,0 mg/m3

Tabel 3. Proporsi Kapasitas Fungsi Paru pada Perajin Batu Paras

\begin{tabular}{lcc}
\hline Kategori & Frekuensi (n) & Proporsi (\%) \\
\hline Normal $^{*}$ & 26 & 43,3 \\
Restriksi & 25 & 41,7 \\
\hline
\end{tabular}




\begin{tabular}{lcc}
\hline Obstruksi & 6 & 10 \\
Mixed & 3 & 5 \\
\hline
\end{tabular}

* Menurut West (2011), dikategorikan normal jika nilai FEV1 $\geq 75 \%$ dan FVC $\geq 80 \%$, obstruksi (FEV1 $<75 \%$ ), restriksi (FVC $<80 \%$ ), atau mixed obstruksi dan restriksi (FEV1 $<75 \%$ dan $\mathrm{FVC}<80 \%$ )

Tabel 4. Hubungan Karakteristik Responden dan Paparan Debu dengan Kapasitas Fungsi Paru

\begin{tabular}{|c|c|c|c|c|c|c|}
\hline \multirow[b]{2}{*}{ Kategori } & \multicolumn{2}{|c|}{ Kapasitas Fungsi Paru } & \multirow[b]{2}{*}{$\begin{array}{c}\text { Total } \\
(n=60)\end{array}$} & \multirow[b]{2}{*}{ PR } & \multirow[b]{2}{*}{$\begin{array}{c}95 \% \\
\text { CI }\end{array}$} & \multirow[b]{2}{*}{$\mathbf{p}$} \\
\hline & $\begin{array}{c}\text { Gangguan } \\
(\mathrm{n}=34)\end{array}$ & $\begin{array}{c}\text { Normal } \\
(n=26)\end{array}$ & & & & \\
\hline \multicolumn{7}{|l|}{ Umur } \\
\hline$<30$ tahun & $4(26,7 \%)$ & $11(73,3 \%)$ & $15(100 \%)$ & 2,5 & $1,05-$ & 0,006 \\
\hline$\geq 30$ tahun & $30(66,7 \%)$ & $15(33,3 \%)$ & $45(100 \%)$ & & 5,93 & \\
\hline \multicolumn{7}{|l|}{ Status Gizi } \\
\hline Normal & $14(43,7 \%)$ & $18(56,3 \%)$ & $32(100 \%)$ & 1,63 & $1,03-$ & 0,030 \\
\hline Tidak normal & $20(71,4 \%)$ & $8(28,6 \%)$ & $28(100 \%)$ & & 2,57 & \\
\hline \multicolumn{7}{|l|}{ Masa Kerja } \\
\hline$<8$ tahun & $5(27,8 \%)$ & $13(72,2 \%)$ & $18(100 \%)$ & 2,48 & $1,14-$ & 0,003 \\
\hline$\geq 8$ tahun & $29(69 \%)$ & $13(31 \%)$ & $42(100 \%)$ & & 5,37 & \\
\hline
\end{tabular}

Kebiasaan

Merokok

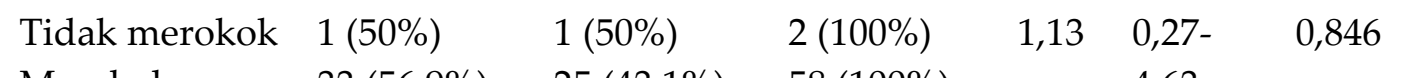

Merokok $33(56,9 \%) \quad 25(43,1 \%) \quad 58(100 \%) \quad 4,63$

Penggunaan

APD

\begin{tabular}{lllllll} 
Baik & $3(40 \%)$ & $2(60 \%)$ & $5(100 \%)$ & 1,45 & $0,48-$ & 0,432 \\
Tidak baik & $32(58,2)$ & $23(41,8)$ & $55(100 \%)$ & & 4,35 & \\
\hline $\begin{array}{l}\text { Durasi Kerja } \\
\leq 8 \text { jam }\end{array}$ & $19(46,3 \%)$ & $22(53,7 \%)$ & $41(100 \%)$ & 1,70 & $1,13-$ & 0,017 \\
$>8$ jam & $15(79 \%)$ & $4(21 \%)$ & $19(100 \%)$ & & 2,54 & \\
\hline $\begin{array}{l}\text { Paparan Debu } \\
\leq \text { NAB }\end{array}$ & $22(48,9 \%)$ & $23(51,1 \%)$ & $45(100 \%)$ & 1,63 & $1,10-$ & 0,035 \\
$>$ NAB & $12(80 \%)$ & $3(20 \%)$ & $15(100 \%)$ & & 2,42 & \\
\hline
\end{tabular}

Berdasarkan pada Tabel 1, karakteristik responden responden paling banyak berada pada kelompok umur 3039 tahun (53,3\%), seluruh responden berjenis kelamin laki-laki (100\%), sebagian besar responden memiliki status gizi normal (53,3\%), mayoritas responden memiliki masa kerja $\geq 8$ tahun $(70 \%)$, hampir semua responden adalah perokok $(96,7 \%)$ dan tidak menggunakan alat pelindung diri (APD) (91,7\%), serta 
sebagian besar responden dalam durasi kerja standar $(\leq 8$ jam $)(68,3 \%)$.

Tabel 2 menunjukkan bahwa mayoritas responden $75 \%$ bekerja dengan paparan debu $\leq$ NAB $\left(3,0 \mathrm{mg} / \mathrm{m}^{3}\right)$. Dari hasil penelitian juga ditemukan bahwa mayoritas responden mengalami gangguan fungsi paru 56,7\% (Tabel 3).

Hubungan antara faktor individu dan paparan debu dengan kapasitas fungsi paru ditampilkan pada Tabel 4. Faktor yang berhubungan secara signifikan dengan kapasitas fungsi paru adalah umur ( $\mathrm{p}=0,006 ; 95 \%$ CI 1,05-5,93), status gizi ( $\mathrm{p}=0,030 ; 95 \% \mathrm{CI} 1,03-2,57)$, masa kerja $(\mathrm{p}=0,003 ; 95 \%$ CI 1,14-5,37), durasi kerja $(\mathrm{p}=0,017 ; 95 \%$ CI 1,13-2,54), dan paparan debu ( $\mathrm{p}=0,035 ; \quad 95 \%$ CI 1,10-2,42). Kebiasaan merokok ( $p=0,846$; 95\% CI 0,274,63 ) dan penggunaan APD ( $\mathrm{p}=0,432 ; 95 \%$ CI 0,48-4,35) tidak menunjukkan ada hubungan dengan kapasitas fungsi paru.

Tabel 5. Analisis Multivariabel Paparan Debu dengan Kapasitas Fungsi Paru pada Perajin Batu Paras

\begin{tabular}{|c|c|c|c|c|c|c|}
\hline \multirow{3}{*}{ Variabel } & \multicolumn{2}{|c|}{ Kapasitas Fungsi Paru } & \multicolumn{4}{|c|}{ Model Akhir } \\
\hline & \multirow{2}{*}{$\begin{array}{c}\text { Gangguan } \\
(\mathrm{n}=34)\end{array}$} & \multirow{2}{*}{$\begin{array}{c}\text { Normal } \\
(n=26)\end{array}$} & \multirow{2}{*}{ p } & \multirow{2}{*}{ AOR } & \multicolumn{2}{|c|}{ 95\% C.I.for OR } \\
\hline & & & & & Lower & Upper \\
\hline \multicolumn{7}{|l|}{ Penggunaan APD } \\
\hline Baik & $2(40 \%)$ & $3(60 \%)$ & 0,21 & 3,86 & 0,46 & 32,50 \\
\hline Tidak Baik & $32(58,2)$ & $23(41,8)$ & & & & \\
\hline \multicolumn{7}{|l|}{ Status Gizi } \\
\hline Normal & $14(43,7 \%)$ & $18(56,3 \%)$ & 0,02 & 4,30 & 1,30 & 14,30 \\
\hline Tidak Normal & $20(71,4 \%)$ & $8(28,6 \%)$ & & & & \\
\hline \multicolumn{7}{|l|}{ Paparan Debu } \\
\hline$\leq \mathrm{NAB}\left(3,0 \mathrm{mg} / \mathrm{m}^{3}\right)$ & $22(48,9 \%)$ & $23(51,1 \%)$ & 0,04 & 4,70 & 1,10 & 20,24 \\
\hline$>\operatorname{NAB}\left(3,0 \mathrm{mg} / \mathrm{m}^{3}\right)$ & $12(80 \%)$ & $3(20 \%)$ & & & & \\
\hline
\end{tabular}

Dari hasil analisis multivariabel (Tabel 5) didapatkan bahwa faktor risiko yang paling bermakna memengaruhi kapasitas fungsi paru adalah paparan debu dengan adjusted odds ratio (AOR) sebesar 4,70 kali meningkatkan gangguan kapasitas fungsi paru pada kelompok yang memiliki paparan debu lebih dari NAB (>3,0 mg/m3) (95\% CI 4,70-20,24).

\section{DISKUSI}

Terdapat hubungan bermakna antara umur responden terhadap kapasitas fungsi paru dengan risiko lebih tinggi pada responden yang berumur lebih dari 30 tahun. Adanya hubungan antara variabel umur dan kapasitas fungsi paru juga ditemukan dalam penelitian yang dilakukan oleh Larasati (2015) pada pekerja batu bara di PT.X Surabaya. Guyton (2007) mengatakan bahwa mulai dari masa anak-anak hingga dewasa sekitar 24 tahun kapasitas paru seseorang akan berkembang dan mencapai optimum dan setelah itu akan menetap (stationer) sampai pada usia 30 tahun, kemudian menurun secara gradual sesuai pertambahan usia.

Pada variabel status gizi menyatakan bahwa terdapat hubungan bermakna antara status gizi dengan 
kapasitas fungsi paru pada responden dengan risiko lebih tinggi pada responden yang memiliki status gizi tidak normal. Adanya hubungan antara variabel status gizi dengan kapasitas fungsi paru juga ditemukan dalam penelitian yang dilakukan oleh Larasati (2015) pada pekerja batu bara di PT.X Surabaya. Tetapi hasil penelitian berbeda diperoleh oleh Faiz (2014) pada pekerja operator SPBU di Ciputat yang mengatakan bahwa tidak terdapat hubungan antara status gizi dengan kapasitas fungsi paru. Costa, dkk (2008) menyatakan bahwa individu dengan tingkat gizi tidak normal lebih rentan terhadap berbagai penyakit infeksi karena imunitas tubuh yang lemah. Seperti halnya individu yang memiliki status gizi berlebih (obesitas) juga tidak baik terhadap kapasitas fungsi paru, dimana akan terdapat tambahan jaringan adiposa yang akan menekan rongga dada, abdomen dan paru.

Terdapat hubungan bermakna antara masa kerja dengan kapasitas fungsi paru responden. Adanya hubungan antara variabel masa kerja dan kapasitas fungsi paru juga ditemukan dalam penelitian yang dilakukan oleh Larasati (2015) pada pekerja batu bara di PT.X Surabaya. Tetapi hasil penelitian berbeda diperoleh oleh Tamuntuan, dkk (2013) pada pekerja di bagian pengecatan mobil di CV. Kombos Manado yang mengatakan bahwa tidak terdapat hubungan antara masa kerja dengan kapasitas fungsi paru. Suma'mur (2013) menyatakan bahwa semakin lama seseorang dalam bekerja maka semakin banyak dia telah terpapar bahaya yang ditimbulkan dari lingkungan kerja tersebut.
Pada variabel kebiasaan merokok menyatakan bahwa tidak terdapat hubungan bermakna antara kebiasaan merokok dengan kapasitas fungsi paru pada responden. Tidak adanya hubungan antara variabel kebiasaan merokok dengan kapasitas fungsi paru juga ditemukan dalam penelitian yang dilakukan oleh Putra (2012) pada juru parker di Jalan Pandanaran Semarang. Tetapi hasil penelitian berbeda diperoleh oleh Oviera, dkk (2016) pada pekerja industri pengolahan kayu di PT.X Jepara yang mengatakan bahwa terdapat hubungan antara kebiasaan merokok dengan kapasitas fungsi paru. Putra (2012) menyatakan bahwa ketidaksesuaian tersebut dikarenakan dalam penelitian ini tidak memperhitungkan aspek lain dari kebiasaan merokok seperti jenis rokok yang dihisap, dan cara menghisap rokok.

Pada variabel penggunaan alat pelinung diri (APD) tidak terdapat hubungan bermakna antara penggunaan alat pelindung diri (APD) dengan kapasitas fungsi paru responden. Tidak adanya hubungan antara variabel penggunaan alat pelindung diri (APD) dan kapasitas fungsi paru juga ditemukan dalam penelitian yang dilakukan oleh Oviera, dkk (2016) pada pekerja industri pengolahan kayu di PT. X Jepara yang menyatakan bahwa tidak terdapat hubungan antara penggunaan alat pelindung diri (APD) dengan kapasitas fungsi paru. Tetapi hasil penelitian berbeda diperoleh oleh Dian, R.P (2010) yang mengatakan bahwa terdapat hubungan antara penggunaan alat pelindung diri (APD) dengan kapasitas fungsi paru pada pekerja bengkel las di 
Pisangan Ciputat. Dian, R.P (2010) menyatakan bahwa penggunaan alat pelindung diri (APD) secara rutin dan benar bukan berarti akan menghentikan paparan debu yang ada, namun dapat mengurangi paparan dari debu tersebut sehingga risiko gangguan kapasitas fungsi paru dapat berkurang.

Terdapat hubungan bermakna antara durasi kerja dengan kapasitas fungsi paru pada responden dengan risiko lebih tinggi pada responden yang memiliki status durasi kerja kurang dari sama dengan 8 jam ( $\leq 8$ jam). Tetapi hasil penelitian berbeda diperoleh oleh Pinugroho, dkk (2017) pada pekerja mebel di Kecamatan Kalijambe, Sragen yang mengatakan bahwa tidak terdapat hubungan antara durasi kerja dengan kapasitas fungsi paru. Laga, dkk (2013) menyatakan bahwa semakin lama durasi kerja menghabiskan waktu untuk bekerja di area kerjanya, maka akan semakin lama pula paparan debu yang akan dihirup.

Berdasarkan hasil perhitungan statistik, di dapat bahwa proporsi kapasitas fungsi paru lebih tinggi pada responden yang hasil pengukuran paparan debu dibawah NAB $(\leq 3 \mathrm{mg} / \mathrm{m} 3)$ sebesar $48,9 \%(p=0,035)$ dengan risiko 1,63 kali lebih tinggi mengalami gangguan fungsi paru pada kelompok paparan debu (95\% CI 1,10-2,42). Hasil penelitian ini serupa dengan penelitian yang dilakukan oleh Aji (2010) menyatakan bahwa paparan debu berpengaruh terhadap kapasitas fungsi paru pada pekerja penggilingan padi di Kecamatan Karanganyar Kabupaten Karanganyar $(p=0,003)$. Tetapi hasil penelitian berbeda diperoleh oleh Larasati (2015) yang menyatakan bahwa tidak terdapat hubungan bermakna antara paparan debu dengan kapasitas fungsi paru.

Hubungan paparan debu dengan kapasitas fungsi paru adalah paparan debu yang terhirup ke dalam saluran pernapasan akan menyebabkan timbulnya reaksi mekanisme pertahanan nonspesifik yaitu berupa bersin, batuk, dan lainnya. Kemudian partikel-partikel debu yang terhirup tersebut akan membentuk suatu fokus kemudian berkumpul di bagian awal saluran limfe paru. Sehingga apabila terpapar debu dalam jangka waktu yang lama akan menimbulkan penyakit akibat kerja berupa gangguan kapasitas fungsi paru.

Berdasarkan hasil analisis multivariabel, pada model akhir didapatkan hasil bahwa terdapat hubungan secara bersama-sama antara variabel penggunaan alat pelindung diri (APD), status gizi, dan paparan debu dengan kapasitas fungsi paru.

Paparan debu merupakan variabel yang paling signifikan berhubungan dengan kapasitas fungsi paru pada responden dengan risiko sebesar 4,70 kali lebih besar pada responden yang hasil pengukuran debu dilingkungan kerja kurang dari sama dengan NAB $(\leq 3$ $\mathrm{mg} / \mathrm{m} 3)$. Hasil penelitian ini sejalan dengan hasil penelitian yang dilakukan oleh Yulaekah (2007) terhadap pekerja industri batu kapur yang menyatakan bahwa pada pekerja yang terpapar debu kurang dari $\mathrm{NAB}(3,0 \mathrm{mg} / \mathrm{m} 3)$ berisiko mengalami gangguan fungsi paru sebesar 5,12 kali lebih besar (95\% CI 1,57 - 16,71) dibandingkan dengan kelompok pekerha 
yang terpapar debu lebih dari NAB $(3,0$ $\mathrm{mg} / \mathrm{m} 3)$.

Selain itu, pada responden dengan status gizi tidak normal memiliki risiko sebesar 4,30 (95\% CI 4,30 - 14,30) kali lebih besar untuk mengalami gangguan kapasitas fungsi paru dibandingkan dengan responden dengan status gizi normal. Hasil penelitian ini juga sesuai dengan penelitian yang dilakukan oleh Larasati (2015).

Penggunaan alat pelindung diri (APD) dengan kategori tidak baik pada responden memiliki risiko sebesar 3,86 (95\% CI 0,46 - 32,50) kali lebih besar untuk mengalami gangguan kapasitas fungsi paru dibaningkan dengan responden yang masuk kedalam kategori baik dalam penggunaan alat pelindung diri (APD). Hasil pada penelitian ini juga sesuai dengan hasil penelitian yang dilakukan oleh Awang (2017) pada pekerja di pabrik gula X Kabupaten Lampung Tengah yang menyatakan bahwa pekerja yang tidak menggunakan alat pelindung diri (APD) memiliki hubungan bermakna dengan kapasitas fungsi paru 12,15 kali lebih besar dibandingkan dengan yang menggunakan alat pelindung diri (APD) (95\% CI 1,44 102,62).

\section{SIMPULAN}

Berdasarkan pemaparan hasil, maka dapat disimpulkan bahwa, paparan debu merupakan variabel yang paling signifikan berhubungan dengan kapasitas fungsi paru $(\mathrm{OR}=4,70)$. Berdasarkan karateristik responden dan paparan debu, gangguan kapasitas fungsi paru lebih tinggi pada responden berumur $\geq 30$ tahun, responden dengan status gizi tidak normal, masa kerja $\geq 8$ tahun, kebiasaan merokok, penggunaan alat pelindung dirinya tidak baik, durasi kerja $\leq 8$ jam, dan hasil pengukuran paparan debu kurang dari sama dengan nilai ambang batas (NAB) $(0,3 \mathrm{mg} / \mathrm{m} 3)$. Terdapat hubungan antara umur, status gizi, masa kerja, durasi kerja, dan paparan debu dengan kapasitas fungsi paru, sedangkan kebiasaan merokok dan penggunaan alat pelindung diri tidak menunjukkan hubungan.

\section{SARAN}

Pemilik usaha agar bekerjasama dengan puskesmas desa untuk memberi penyuluhan terhadap tenaga kerja terkait bahaya paparan debu, pemberian masker dan menekankan penggunaan alat pelindung diri.

\section{DAFTAR PUSTAKA}

Aji, Sari Sakti. 2010. Hubungan Paparan Debu dengan Kapasitas Fungsi Paru Pekerja Penggilingan Padi di Kecamatan Karanganyar Kabupaten Karanganyar. [Skripsi]. Surakarta: Fakultas Kedokteran Universitas Sebelas Maret.

Awang, Astrid Sulistomo, M Junus DH. 2017. Gambaran Fungsi Paru dan Faktor-faktor yang Berhubungan pada Pekerja Terpapar Debu Bagasse di Pabrik Gula X Kabupaten Lampung Tengah. Jakarta: Dapartemen Ilmu Kedokteran Komunitas, Fakultas Kedokteran, Universitas Indonesia. Costa, Barbalho MC, Miguel GP, Forti EM, Azevedo JL. 2008. The Impact of Obesity on Pulmonary Fuction in Adult Women. Clinic. 63:719-24. 
Dian, R. P. 2010. Faktor-faktor yang Berhubungan dengan Kapasitas Vital Paru pada Pekerja Bengkel Las di Pisangan Ciputat Tahun 2010. [Skripsi]. Jakarta: Fakultas Kedokteran dan Ilmu Kesehatan Universitas Islam Negeri Syarif Hidayatullah.

Guyton, Arthur C. 2007. Buku Ajar Fisiologi Kedokteran. Edisi 11. Jakarta: ECG.

International Labour Organization. 2002. Guidelines for the use of the ILO International Classification of Radiographs of Pneumoconiosis. Revised edition 2000. Geneva: International Labour Office.

Keputusan Presiden Nomor 22 Tahun 1993 tentang Penyakit yang Timbul Karena Hubungan Kerja. Diakses pada 17 Februari 2019. https:/peraturan.bkpm.go.id/jdih/ userfiles/batang/Kepres 22 1993.p $\underline{\mathrm{df}}$

Laga, Syamsiar Russeng, Atjo Wahyu. 2013. Faktor yang Berhubungan dengan Kapasitas Paru Tenaga Kerja di Kwasan Industri Mebel Antang Makassar. Makassar: Bagian Kesehatan dan Keselamatan Kerja, FKM UNHAS.

Larasati, Yosi. 2015. Pengaruh Paparan Debu Batu Bara Terhadap Status Faal Paru Pekerja di PT.X Surabaya. [Skripsi]. Surabaya: Universitas Airlangga.

Oviera, Siswi Jayanti, Suroto Suroto. 2016. Faktor-faktor yang Berhubungan dengan Kapasitas Vital Paru pada Pekerja Industri Pengolahan Kayu di Pt. X Jepara. Jurnal Kesehatan Masyarakat (e-Journal). Vol. 4, No.1.
Peraturan Menteri Tenaga Kerja dan Transmigrasi Republik Indonesia Nomor PER. 13/MEN/X/2011 tentang Nilai Ambang Batas Faktor Fisika dan Faktor Kimia di Tempat Kerja.

Pinugroho, Yuli Kusumawati. 2017. Hubungan Usia, Lama Paparan Debu, Penggunaan APD, Kebiasaan Merokok dengan Gangguan Fungsi Paru Tenaga Kerja Mebel di Kec. Kalijambe Sragen. Jurnal Kesehatan. ISSN 1979-7621, Vol. 10, No. 2.

Putra, Dian. 2012. Hubungan Usia, Lama Kerja, dan Kebiasaan Merokok dengan Fungsi Paru pada Juru Parker di Jalan Pandanaran Semarang. Jurnal Kedokteran Muhammadiyah.Vol. 1, No. 3.

Suma'mur, P.K. 2013. Higiene Perusahaan dan Kesehatan Kerja (HIPERKES). Jakarta: Sagung Seto.

Tamuntuan, Ricky C. Sondakh, Jimmy Rumampuk. 2013. Hubungan Antara Masa Kerja dengan Kapasitas Vital Paru pada Pekerja di Bagian Pengecatan Mobil di CV. Kombos Manado. Manado: Bidang Minat Kesehatan Kerja, Fakultas Kesehatan Masyarakat Universitas Sam Ratulangi Manado.

Yulaekah, Siti. 2007. Paparan Debu terhirup dan Gangguan Fungsi Paru pada Pekerja Industri Batu Kapur. [Tesis]. Semarang: Universitas Diponegoro. 